\title{
Interpretasi Konsep Interior pada Tiga Ruang Museum House of Sampoerna Surabaya Berdasarkan Visualisasi Ruangan
}

\section{Interpretation of Interior Concept in Three Rooms of Surabaya's House of Sampoerna Museum Based on the Room Visualization}

\author{
Rania Erin Oktiara, Lilik Indrawati*, Swastika Dhesti Anggriani \\ Universitas Negeri Malang, Jl. Semarang No. 5 Malang, Jawa Timur, Indonesia \\ *Penulis korespondensi, Surel: lilik.indrawati.fs@um.ac.id
}

Paper received: 02-01-2021; revised: 15-01-2021; accepted: 30-01-2021

\begin{abstract}
Abstrak
Museum merupakan lembaga yang mengumpulkan dan merawat benda-benda yang memiliki nilai sejarah untuk dipamerkan dan difungsikan sebagai sarana edukasi kepada masyarakat umum. Penyampaian fungsi tersebut dipengaruhi oleh konsep interior melalui visualisasi pada setiap ruangannya. Salah satu museum yang menarik peneliti untuk menginterpretasi penerapan konsepnya yaitu Museum House of Sampoerna Surabaya. Museum ini tercatat sebagai salah satu bangunan cagar budaya di Kota Surabaya. Museum ini menampilkan sejarah pendirian dan berkembangnya perusahaan Sampoerna yang bersifat tematik pada masing-masing ruangannya, sehingga terdapat tema yang berbeda-beda meskipun masih dalam satu ruangan. Adanya penerapan visualisasi tersebut yang melandasi tujuan penelitian ini untuk menginterpretasi konsep interior yang diterapkan berdasarkan visualisasi ruangannya. Museum House of Sampoerna terdiri atas 5 ruang pamer, akan tetapi pada penelitian ini hanya menginterpretasi 3 ruang pamer yang tidak mengalami perubahan interior secara signifikan sejak tahun 2018, yang disebutkan sebagai ruang 1 , ruang 2 , ruang 3 . Penelitian ini menggunakan metode pengumpulan data observasi, wawancara, serta analisis dokumen yang melibatkan interpretasi peneliti. Berdasarkan hasil penelitian ini dapat diketahui konsep interior yang diterapkan pada ruang 1, ruang 2, dan ruang 3.
\end{abstract}

Kata kunci: konsep, interior, museum, House of Sampoerna, visualisasi

\begin{abstract}
A museum is an institution that collects and looks after historical objects to showcase and function them as educational media for the public. The realization of those functions depends on the interior concept through visualization in each room. One museum that is particularly attractive to the researcher to analyze is Surabaya House of Sampoerna Museum. This museum is recorded to be one of Surabaya's cultural heritage buildings. It displays the history of the establishment and the development of Sampoerna company thematically in each room in the building, therefore, there are different themes even in one room. The implementation of the mentioned visualization concept has become the basis of interpretation for the researcher with the focus on room visualization. House of Sampoerna Museum consists of five showcase rooms; however, this research only interprets three rooms that do not undergo significant alteration since 2018. The three rooms are referred to as room 1 , room 2, room 3. The data collection methods of this research are observation, interview, and document analysis that involves the researcher's interpretation. Based on the results of this research, the interior concepts of room 1, room 2, and room 3 have been discovered.
\end{abstract}

Keywords: concept, interior, museum, House of Sampoerna, visualization

\section{Pendahuluan}

Berdasarkan definisi yang disampaikan oleh International Council of Museum, museum merupakan lembaga nirlaba yang tidak hanya mengoleksi dan merawat suatu barang, namun juga sebagai pusat pengetahuan yang menjadi pemancar ilmu pengetahuan yang bersumber 
dari koleksi dan menjadikannya informasi bagi masyarakat banyak (Munandar dkk, 2011). Berawal dari definisi tersebut, pada masa kini museum dapat digunakan sebagai pusat dokumentasi dan juga penelitian ilmiah. Menurut penelusuran laman media online, Indonesia memiliki banyak museum yang tersebar di berbagai wilayahnya yang menjadi daya tarik bagi wisatawan untuk berkunjung dan menjadi tempat beraktivitas berupa penelitian ilmiah pada museum tersebut. Salah satu museum yang menarik perhatian pada penelitian ini yaitu Museum House of Sampoerna Surabaya.

Museum House of Sampoerna adalah salah satu museum yang terletak di Surabaya dengan alamat Taman Sampoerna No.6, Krembangan Utara, Kecamatan Pabean Cantian, Kota Surabaya, Provinsi Jawa Timur. Museum ini memiliki sejarah panjang tentang PT Sampoerna yang merupakan salah satu perusahaan rokok terbesar di Indonesia dan pasar rokok terbesar ke-5 di dunia yang didirikan oleh Liem Seeng Tee (1893-1956). Perusahaan Sampoerna termasuk salah satu produsen rokok kretek (tembakau dan cengkeh) tertua dan yang berkembang paling pesat hingga saat ini.

Museum ini menampilkan tentang berbagai koleksi yang berhubungan dengan awal mula perintisan karir pendiri Sampoerna, sejarah perjalanan dan perkembangan bisnisnya, serta peralatan dan bahan yang digunakan untuk memproduksi rokok Sampoerna. Selain itu, museum ini juga memiliki ciri khas dengan aroma tembakau dan cengkeh yang tercium ketika pertama kali memasuki ruangannya.

Museum House of Sampoerna ini memiliki visualisasi interior tematik yang di dalamnya masih terdapat sub tema lainnya. Menurut Ching dan Binggeli (2012) interior adalah perencanaan tata letak perancangan ruang dalam pada sebuah bangunan. Keadaan fisiknya dapat mempengaruhi bentuk aktivitas dan memenuhi aspirasi pengunjung. Di samping itu, sebuah interior juga mempengaruhi pandangan serta suasana hati bagi pengunjung. Interior museum diperlukan untuk memaksimalkan fungsi suatu ruangan dalam menjelaskan sejarah yang dimilikinya. Pada interior Museum House of Sampoerna memiliki konsep ruangan yang bersifat tematik. Penataan tematik pada museum ini diangkat dari sejarah pendirian dan berkembangnya perusahaan Sampoerna termasuk awal mula keluarga ini terbentuk, pendirian perusahaan, bahan dan alat produksi yang pernah digunakan, serta perkembangan perusahaan hingga saat ini yang dapat dilihat melalui elemen interiornya serta storyline atau alur sejarah di dalamnya. Adanya perbedaan konsep pada interior museum tersebut mampu menghadirkan nuansa yang berbeda meskipun masih dalam satu ruangan. Adanya perbedaan penerapan visualisasi interior itulah yang melandasi penelitian ini dengan menginterpretasi visualisasi interior museum sehingga dapat diketahui konsep yang digunakan.

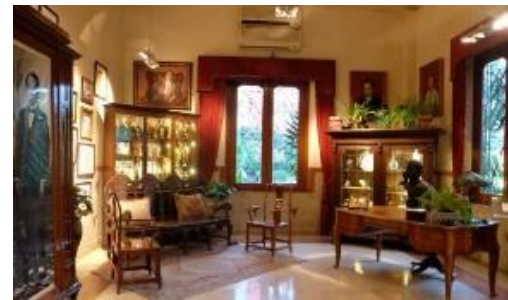

a

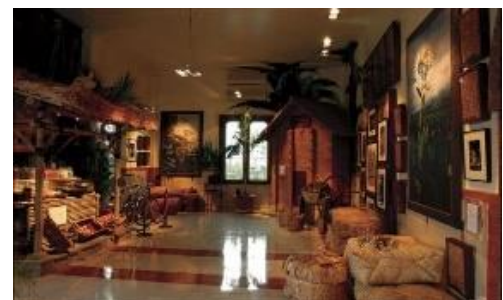

b

Gambar 1. Contoh Perbedaan Visualisasi Interior Dalam Satu Ruangan

(Sumber a: Agmasari/tribunnews.com, 2016) (Sumber b: Rudi/Nativeindonesia.com, 2019) 


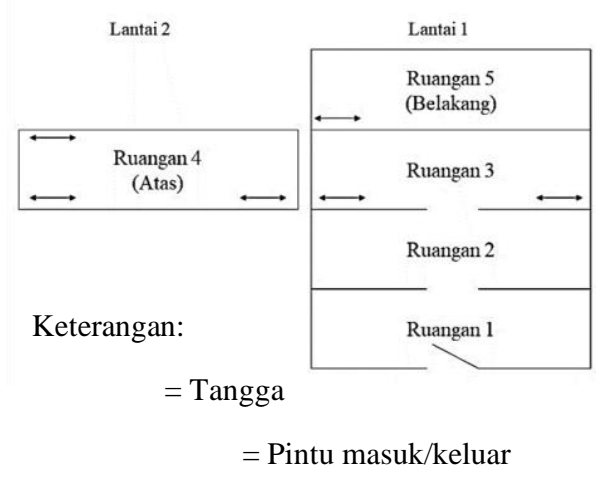

\section{Gambar 2: Denah Ruangan Museum}

Museum ini terdiri atas 5 ruangan yang meliputi 4 ruangan bagian bawah dan 1 ruangan bagian atas. Adapun ruangan yang akan diteliti yaitu ruangan pada lantai 1 bagian depan yang terdiri dari tiga ruangan pamer (ruang 1, ruang 2, dan ruang 3). Pemberian nama ruang bersifat numerik ini berdasarkan letak ruang yang berurutan dari pintu masuk serta supaya mudah mengklasifikasinya pada pemaparan data. Adanya pemilihan ketiga ruang tersebut dikarenakan berdasarkan data yang diperoleh pada observasi awal ruangan tersebut tidak mengalami perubahan interior yang signifikan sejak tahun 2018. Hal tersebut ditunjukkan oleh dokumen foto pada google review serta penelitian sebelumnya. Adanya perubahan interior tersebut menjadi kendala untuk mencari kelengkapan data berupa dokumen foto yang akurat di internet selama museum tutup sementara waktu akibat dampak pandemi virus Covid-19. Maka dari itu, ketiga ruangan tersebut dipilih menjadi objek penelitian karena kemudahan akses dalam mencari kelengkapan data berupa dokumen foto secara online. Pada penelitian ini, peneliti juga belum menemukan adanya penelitian lain yang membahas visualisasi ruangan yang mencoba menginterpretasi penerapan konsep interior tersebut, sehingga penelitian ini dianggap layak dan perlu untuk dilaksanakan. Oleh karena itu, penelitian ini mengangkat judul "Interpretasi Konsep Interior pada Tiga Ruangan Museum House of Sampoerna Surabaya Berdasarkan Visualisasi Ruangan".

\section{Metode}

Penelitian ini menggunakan pendekatan deskriptif kualitatif. Pendekatan deskriptif kualitatif dianggap cocok karena mendeskripsikan hasil temuan berupa interpretasi konsep interior Museum House of Sampoerna berdasarkan data yang telah dikumpulkan dan direduksi.

Sumber data pada penelitian ini terbagi menjadi sumber data primer dan sumber data sekunder (Sugiyono, 2019). Sumber data primer dalam penelitian ini yaitu interior Museum House of Sampoerna (ruang 1, ruang 2, dan ruang 3), sedangkan sumber data sekunder merupakan dokumen dan pihak yang bersangkutan dalam penelitian ini. Dokumen pada penelitian ini meliputi daftar barang koleksi, storyline, katalog digital, foto interior museum, buku, jurnal, dan artikel. Adapun pihak yang bersangkutan dalam penelitian ini yaitu pihak Museum House of Sampoerna serta informan. Informan pada penelitian ini terdiri atas 1 kurator museum, 1 desainer interior museum, 2 desainer interior junior yang pernah melaksanakan project berkaitan dengan interior museum. 
Teknik pengumpulan data pada penelitian ini terdiri atas observasi, analisis dokumen, dan wawancara. Observasi dilakukan secara offline dan online bertujuan untuk mengamati visualisasi interior museum dan memastikan kelengkapan data. Alat bantu yang digunakan saat observasi secara langsung yaitu kamera, dan secara online yaitu aplikasi WhatsApp, Instagram, dan Google. Analisis dokumen bertujuan untuk menganalisis dokumen foto, dokumen tertulis, serta dokumen lembar hasil wawancara. Alat bantu yang digunakan untuk menganalisis dokumen yaitu PDF, Ms. Word, dan aplikasi Calibre. Wawancara kepada informan dalam penelitian ini dilakukan secara online menggunakan aplikasi WhatsApp untuk wawancara sinkron melalui telepon dan juga Google Form untuk wawancara asinkron menggunakan daftar pertanyaan yang telah disajikan.

Analisis data yang digunakan pada penelitian ini adalah model Miles dan Huberman. Model ini dipilih berdasarkan kesesuaian pada proses pengumpulan data yang bersifat saling memberikan bukti temuan satu dengan yang lainnya pada permasalahan yang diangkat. Selain itu, model ini juga memudahkan peneliti untuk menganalisis data berdasarkan jenis pendekatan yang digunakan. Miles dan Huberman (dalam Sugiyono, 2019) mengemukakan bahwa aktivitas dalam analisis data kualitatif dilakukan secara interaktif dan berlangsung secara terus-menerus sampai tuntas, sehingga datanya sudah jenuh. Aktivitas dalam menganalisis data yaitu reduksi data, penyajian data dan menarik kesimpulan.

Teknik pemeriksaan keabsahan data yang sesuai dengan penelitian ini yaitu melalui uji kredibilitas yang mengambil beberapa teknik terpilih yakni teknik ketekunan pengamat, triangulasi teknik/metode, dan kecukupan referensial. Ketiga teknik dari uji kredibilitas tersebut dipilih berdasarkan kesesuaian dengan jenis penelitian, jumlah peneliti, tahapan penelitian, serta data dan sumber data yang didapatkan.

\section{Hasil dan Pembahasan}

\subsection{Elemen Pembentuk Ruang}

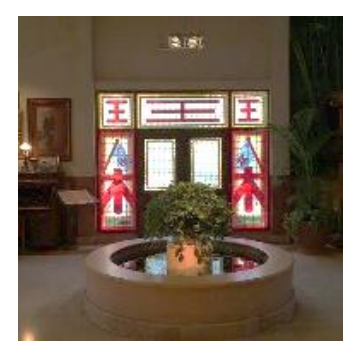

a

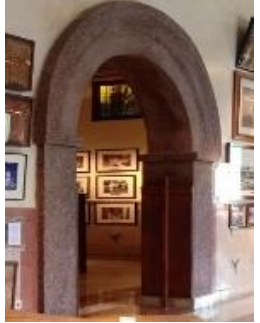

b

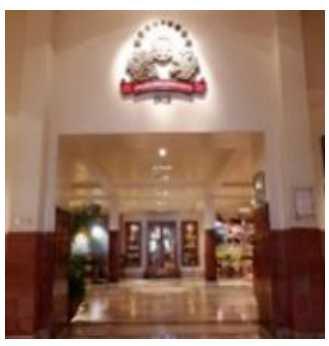

c

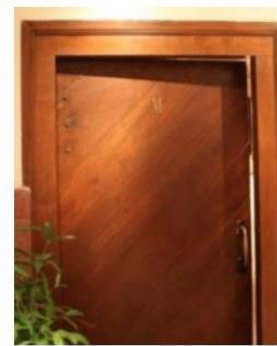

d

Gambar 3. Pintu

(Sumber a: tripadvisor.co.id) (Sumber c: Fahmimnoer/Instagram.com, 2017) (Sumber d: Limantara, Kristianto, \& Kattu, 2017)

Pintu a merupakan pintu utama sebagai akses keluar dan masuk pengunjung ke museum yang terletak pada ruang 1 . Pintu a memiliki visualisasi dengan menempatkan kaca patri bergaya art deco yang bertuliskan huruf Mandarin yaitu Liem “林” yang merupakan marga dari pendiri Sampoerna dan Wang “王” yang berarti raja. Pintu b dan pintu c merupakan pintu penghubung antara ruang satu dengan yang lainnya. Pintu b menghubungkan ruang 1 dan ruang 2 , sedangkan pintu c menghubungkan ruang 2 dan ruang 3. Pintu b memiliki visualisasi karakteristik bangunan Belanda yang terdapat lengkungan pada bagian atasnya dan berbahan 
granit, sedangkan pintu c berbentuk geometri dan terdapat logo Sampoerna di atasnya. Adapula pintu d yang terletak pada ruang 2 sebagai pintu kamar mandi yang terletak pada sisi ruang sebelah kanan maupun sebelah kiri.

Berdasarkan penjelasan di atas, pintu ketiga ruang ini menghubungkan antara ruang satu dengan ruang lainnya (b, c, d) dan ruang luar dengan ruang dalam (a). Tidak hanya itu, pintu ketiga ruang ini juga berfungsi sebagai akses yang dilewati pengunjung maupun akses untuk memindahkan barang koleksi (Ching, 1996).

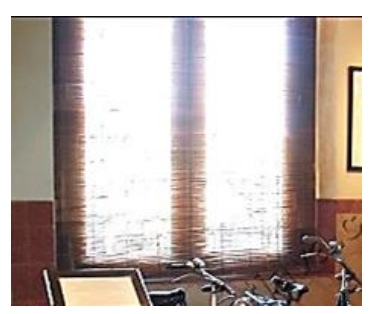

a

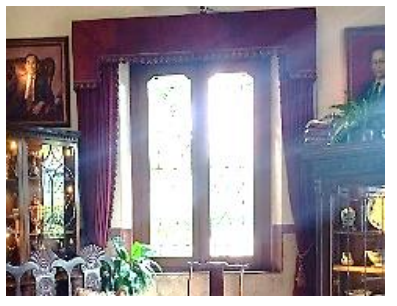

b

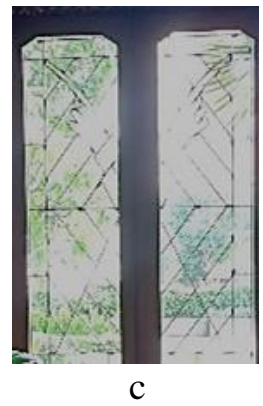

Gambar 4. Jendela Ruang 1

(Sumber a: fajrusmkn1sby/blogspot.com, 2010)

Jendela pada interior Museum House of Sampoerna memiliki visualisasi yang berbedabeda pada setiap ruangannya tergantung fungsi serta kedudukan jendela pada setiap ruangan tersebut. Jendela pada ruang 1 memiliki visualisasi yang menyesuaikan tema ruangan. Jendela a mengangkat tema perintisan karir pendiri Sampoerna yang mengangkat nuansa luar ruangan atau outdoor sehingga menggunakan tirai dari bambu yang juga termasuk bahan dari alam, sedangkan jendela b memiliki tema keluarga Sampoerna sehingga menggunakan kelambu kain berwarna merah. Jendela pada ruang 1 terpengaruh gaya art deco karena berbahan bingkai kayu solid pada daun jendela yang dikombinasikan dengan kaca polos (Young, 2000). Selain itu, kedua jendela pada ruang 1 berbentuk geometris dan menambahkan teralis yang juga mengekspos unsur geometri (c).

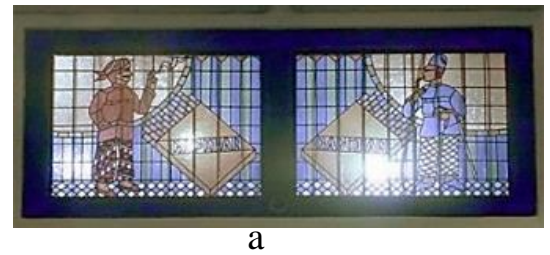

Gambar 5. Jendela Ruang 2

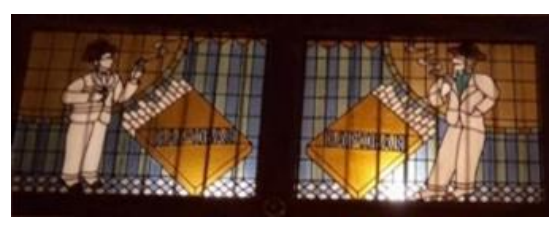

b

(Sumber a: tripadvisor.co.id) (Sumber b: Google Review)

Jendela pada ruangan 2 terbuat dari bahan kaca patri bergaya art deco. Jendela a terletak pada sisi kanan ruangan, sedangkan jendela $b$ terletak pada sisi kiri. Jendela ini memiliki visualisasi dua orang pria yang sedang merokok. Pada jendela a menggambarkan orang Belanda yang mengenakan jas berwarna biru, memiliki rambut blonde, dan berkulit putih, serta masyarakat Indonesia khususnya Jawa yang mengenakan jarik dan blangkon. Pada jendela b menggambarkan karakteristik orang Belanda yang mengenakan busana berwarna putih dan memiliki rambut berwarna blonde. Lalu pada visualisasi pada kedua jendela tersebut 
juga terdapat kata "Dapoean". Dapoean adalah letak kawasan kompleks Sampoerna berdiri dan digunakan sebagai merek awal yang dimiliki Sampoerna. Keberadaan jendela tersebut tidak dapat dijangkau oleh tangan manusia dan tidak dapat dibuka atau biasa disebut dengan jendela kaca mati. Jendela ini memiliki rangka yang tidak dapat digerakkan karena tidak menggunakan engsel (Ching, 1996).

Jendela memiliki fungsi sebagai sirkulasi udara dan cahaya pada suatu ruangan (Wilkening, 1989). Namun berdasarkan penjelasan dan visualisasi gambar di atas, jendela ruang 1 hanya menerapkan fungsinya yang memanfaatkan sinar matahari sebagai sirkulasi cahaya ruang dalam, sedangkan untuk sirkulasi udara memanfaatkan AC karena ruangan sifatnya tertutup. Hal ini serupa dengan jendela ruang 2 yang juga memanfaatkan pendingin ruangan atau AC. Namun, jendela ruang 2 ini hanya sebagai objek estetik saja. Jendela ruang 2 memiliki rangka yang tidak dapat digerakkan karena tidak menggunakan engsel (Ching, 1996). Pada ruang 3 tidak terdapat jendela, sehingga ruangan tersebut seutuhnya memanfaatkan AC dan penerang buatan.

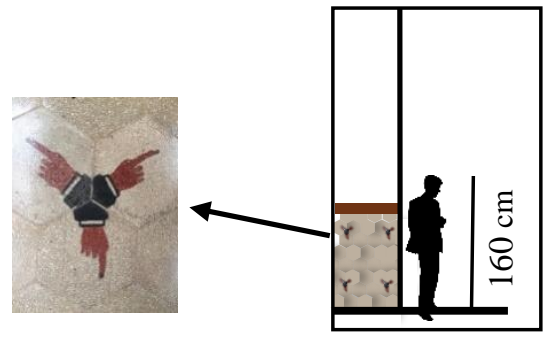

a

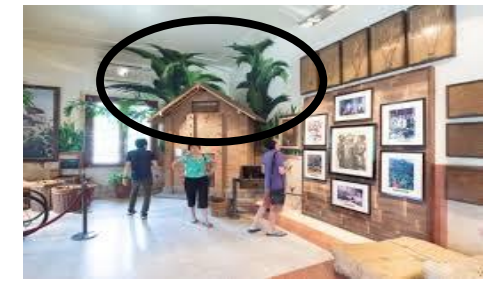

b

Gambar 6. Dinding

Dinding a terdapat pada ruang 1 dan ruang 2 terbagi menjadi dua bagian yakni pada bagian atas memiliki finishing cat putih dan bagian bawah sekitar kurang lebih 1/3 dari tinggi dinding terpasang keramik teraso segienam yang terdapat gambar falsafah tiga tangan, sedangkan pada ruang 3 seutuhnya berwarna putih. Falsafah tiga tangan ini merepresentasikan produsen, penyalur, dan konsumen, yang artinya pihak yang dapat bekerjasama dan saling mendukung satu dengan yang lain untuk meraih kesuksesan.

Dinding pada ruang 1 sebelah kiri terdapat warna dengan visualisasi lukisan tumbuhan yang dapat memberikan kesan tertentu dalam suatu ruangan seperti gambar b (Suptandar, 1985). Dinding ini mendukung tema ruangan yang mengangkat nuansa outdoor dengan memadukan konsep rustic pada barang koleksinya, sedangkan dinding pada ruang 1 sebelah kanan dibiarkan putih polos sesuai dengan nuansa yang dihadirkan layaknya rumah hunian di bagian ruang tamu (a). Visualisasi dinding pada ruang 1 ini sejalan dengan pendapat Suptandar (1985) menyatakan bahwa dinding juga dapat dihias supaya memberikan kesan tertentu pada ruangan dengan cara dicat, dilukis, ditutup atau dilapisi dengan bahan yang menempel pada dinding.

Dinding sebagai pembatas ruangan dapat dirasakan dengan adanya perbedaan tema yang diterapkan antara ruang 1 , ruang 2 , dan ruang 3 . Pernyataan tersebut sesuai dengan pendapat Mangunwijaya (1980) bahwa dinding sebagai pembatas ruangan yang menyangkut batas penglihatan yang biasanya berhubungan dengan suatu kepentingan tertentu. Pada bagian atas dinding ruang 2 berwarna putih polos tanpa tambahan hiasan seperti lukisan atau ornamen hias (a). Lalu pada dinding ruangan 3 memiliki visualisasi warna putih polos dari 
bawah hingga atas menyentuh plafon. Hal tersebut juga menyesuaikan dengan barang koleksi yang ditampilkan pada ruangan ini sebagian besar menutupi permukaan dinding. Pemilihan dinding berwarna putih secara menyeluruh ini menimbulkan efek luas, terasa longgar, dan juga terang (Suptandar, 1985) meskipun ruangan 3 terdapat lebih banyak muatan barang koleksi dibanding ruangan lainnya.

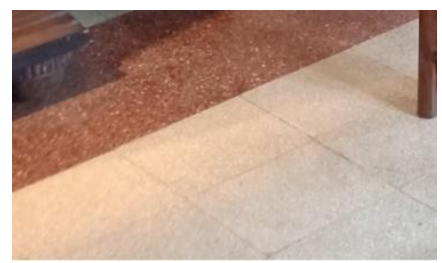

\section{Gambar 7. Lantai}

Lantai ketiga ruangan ini menggunakan jenis teraso dengan bentuk persegi serta motif lantai bintik-bintik kecil. Lantai ini memiliki dua warna yang pada masing-masing ruangan memiliki penataan yang sama yaitu warna merah bata pada bagian pinggir dan warna putih untuk bagian tengah. Penggunaan warna natural ini menjadi ciri khas gaya kolonial klasik Belanda seperti yang dikemukakan Victoria K. Ball (dalam Santoso \& Santosa, 2013) bahwa gaya kolonial klasik Belanda mempunyai karakteristik yang cukup identik dengan menggunakan material yang ada. Sehingga warna-warna yang digunakan cenderung warna natural seperti warna coklat kayu, batu-bata coklat kemerahan, dan putih tulang. Pernyataan tersebut sesuai dengan visualisasi lantai museum yang juga menggunakan warna natural. Selain itu, museum ini juga merupakan bagian dari peninggalan Belanda pada abad 19, sehingga gaya kolonial Belanda masih dapat dirasakan pada interior ruangannya.

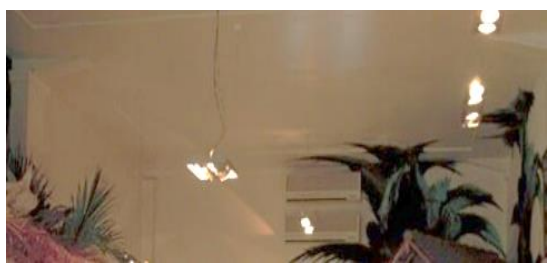

Gambar 8. Plafon

Plafon pada ketiga ruangan menggunakan jenis gypsum berwarna putih. Adanya plafon juga berfungsi sebagai celah untuk menempatkan lampu sorot yang menerangi barang koleksi.

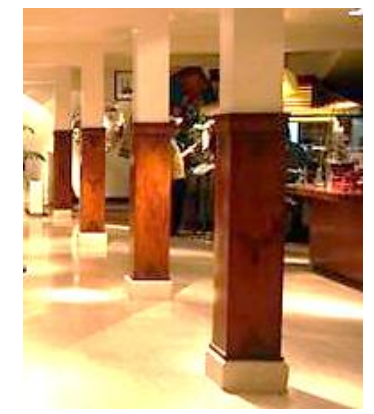

\section{Gambar 9. Tiang/ Kolom}

Pada ruang 3 memiliki karakteristik yang tidak dijumpai pada ruangan lainnya yaitu terdapat $6 \mathrm{kolom} /$ tiang yang berdiri sejajar di tengah-tengah ruangan. Kolom pada ruangan ini memiliki visualisasi terbagi menjadi dua bagian finishing. Pada bagian bawah memiliki finishing menyerupai lapisan kayu dan bagian atas dibiarkan putih polos seperti warna dinding. 
Berdasarkan pemaparan data di atas dapat disimpulkan bahwa elemen pembentuk ruang 1 dan ruang 2 terdiri atas pintu, jendela, dinding, lantai, dan plafon, sedangkan elemen pembentuk ruang 3 terdapat kolom/ tiang dan tidak terdapat jendela. Ketiga ruangan tersebut dihubungkan dengan adanya pintu. Pintu pada ketiga ruang ini terdiri dari satu pintu utama untuk akses keluar dan masuk museum, dan empat pintu yang menghubungkan antara ruang satu dengan yang lainnya (2 pintu penghubung antara ketiga ruang, 2 pintu kamar mandi pada ruang 2). Masing-masing pintu pada ruangan tersebut memiliki visualisasi yang berbeda, dan satu di antaranya melambangkan filosofi pendiri perusahaan, yaitu pada pintu utama/pintu masuk. Bukaan ruang lainnya terletak pada jendela. Adanya jendela pada ruangan museum ini tidak bisa dirasakan manfaatnya sebagai sirkulasi udara dan cahaya. Hal ini dikarenakan setiap ruangannya memanfaatkan pendingin ruangan (AC) dan lampu. Namun demikian, jendela pada ruang 1 masih membantu penerangan ruang ketika siang hari. Jendela pada ruangan museum ini ada yang berfungsi untuk mendukung tema ruangan (ruang 1) dan sebagai objek estetis (ruang 2). Ruangan ini juga dibentuk oleh dinding yang memiliki perbedaan visualisasi antara ruang satu dengan yang lainnya dikarenakan menyesuaikan dengan barang koleksi dan tema yang ditampilkan. Elemen pembentuk lainnya terletak pada lantai yang menggunakan bahan teraso dan juga plafon yang menggunakan gypsum.

\subsection{Furnitur Utama/ Barang Koleksi}

\subsubsection{Furnitur Utama/ Barang Koleksi Ruang 1}

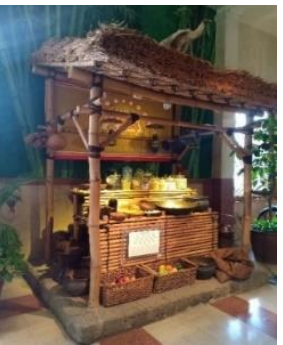

a

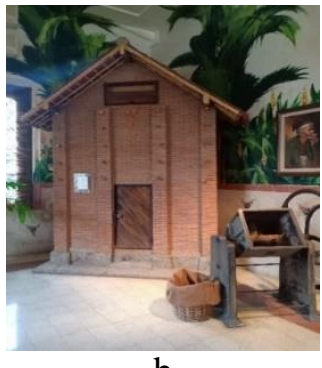

b

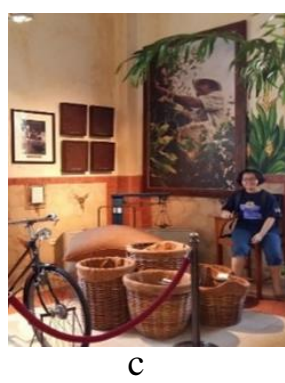

C

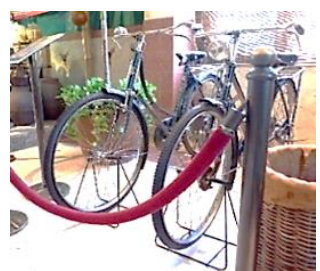

d

Gambar 10. Furnitur Utama Ruang 1A

(Sumber c: Andy Setiabudi/Google Review) (Sumber d: Fahminoer/Instagram.com, 2017)

Furnitur utama pada ruang 1A terletak pada ruang 1 sisi sebelah kiri. Ruangan ini memiliki gaya vintage yang mengangkat nuansa outdoor atau luar ruangan sehingga meletakkan barang koleksi yang semestinya berada di luar ruangan seperti replika warung (a), oven pengering tembakau dan mesin pengurai tembakau (b), alat produksi manual yang digunakan pada masa lampau (c), serta sepeda ontel milik Liem Seeng Tee (d). Furnitur utama ini juga mendukung adanya konsep rustic karena memasukkan variasi bentuk alam dan unsur natural seperti peletakkan kayu tanpa adanya proses finishing dan memiliki elemen interior yang mendukung suasana pedesaan (Wicaksono dan Tisnawati, 2014). Pada ruangan ini memiliki tema tentang awal mula perintisan karir Liem Seeng Tee dalam memulai bisnisnya. Oleh karena itu, furnitur yang ditampilkan cenderung tradisional dan manual. 

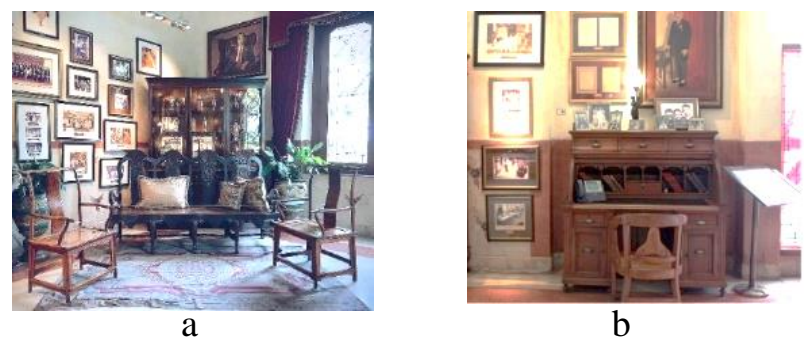

b

Gambar 11. Furnitur Utama Ruang 1B

(Sumber a: Wardhani/TripZilla.id, 2020) (Sumber b: sintiaastarina.com, 2019)

Furnitur utama pada ruang 1B terletak pada ruang 1 sisi sebelah kanan. Gaya pada furnitur ini juga termasuk gaya vintage art deco. Pemilihan material kayu pada furnitur bergaya art deco ini yang pada masanya sering digunakan bangsa Belanda di Indonesia. Ruangan 1B memiliki tema tentang keluarga Sampoerna. Oleh karena itu, furnitur yang dihadirkan layaknya nuansa pada ruang tamu atau ruang keluarga seperti satu set kursi ruang tamu (a) dan satu set meja dan kursi kayu (b).

Berdasarkan penjelasan diatas, fungsi adanya furnitur pada ruang 1 berguna untuk mengoptimalkan fungsi ruang yang dapat dirasakan melalui furnitur pada ruangan tersebut (Wicaksono \& Tisnawati, 2014). Hal itu dikarenakan furnitur pada ruang 1 bersifat mendukung tema ruangan dan menghadirkan kesan yang berbeda antara ruang sebelah kanan (1A) dan ruang sebelah kiri (1B). Ruang $1 \mathrm{~A}$ dan $1 \mathrm{~B}$ menampilkan perbedaan cerita yang dapat dilihat melalui furnitur utamanya, hal ini dapat dikategorikan termasuk ke dalam konsep eklektik yang berarti berkaca pada masa lampau yang di dalamnya terdapat beragam cerita sejarah (Amorani dalam Tanoko, 2013).

\subsubsection{Furnitur Utama/ Barang Koleksi Ruang 2}

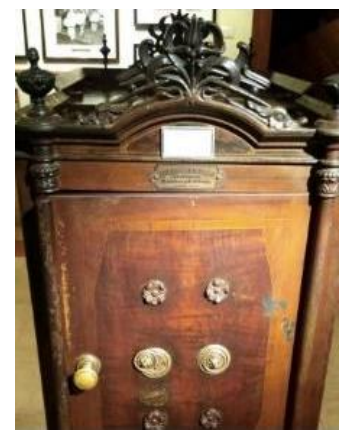

Gambar 12. Furnitur Utama Ruang 2

(Sumber: Unic0rn1902/Instagram.com, 2018)

Pada ruang 2 barang koleksi yang termasuk furnitur utama hanya terdapat pada brankas kuno. Brankas ini berukuran sekitar 1,5m X 0,5m X 0,5m berbahan kayu pada bagian luarnya dan besi baja pada bagian dalamnya (Jelajah Nesia 2, 2015). Kehadiran brankas kuno ini tidak bisa dikatakan sebagai penunjang tema ruangan karena sifatnya tunggal, yang berarti furnitur utama tidak diikuti furnitur pendukung sehingga tidak menimbulkan cerita atau suasana apapun. 


\subsubsection{Furnitur Utama/ Barang Koleksi Ruang 3}

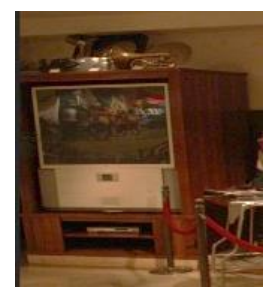

$\mathrm{a}$

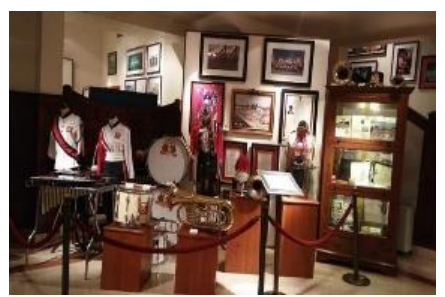

b

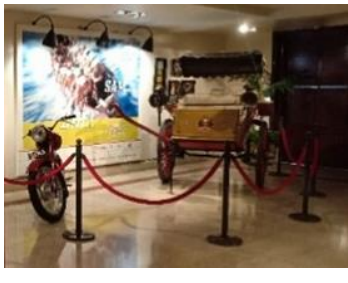

e

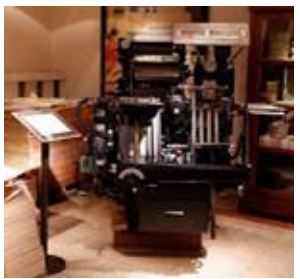

c

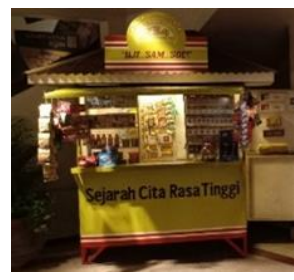

f

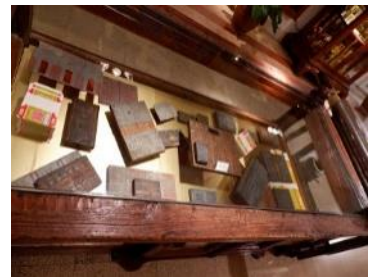

d

Gambar 13. Furnitur Utama Ruang 3

(Sumber a: Tridharyoko/Wordpress.com, 2010) (Sumber b: Fauziah/Travel.detik.com, 2016) (Sumber c: Letsgomuseum.blogspot.com, 2016) (Sumber d: Letsgomuseum.blogspot.com, 2016)

Furnitur pada ruang 3 dibedakan menjadi beberapa sub tema seperti peletakan Marchingband Sampoerna (b), mesin cetak kuno (c), plat cetak kuno (d), motor kuno dan kereta kuda (e) yang terlihat mengelompok berdasarkan kategorinya. Adapun furnitur utama yang tidak memiliki sejarah masa lalu seperti TV (a) dan photobooth warung (f). TV tersebut merupakan TV masa kini untuk memutar profil perusahaan, sedangkan pada photobooth, pengunjung bisa berinteraksi dengan barang yang terdapat di dalamnya. Furnitur pada ruang 3 ini juga termasuk ke dalam gaya vintage.

Berdasarkan penjelasan furnitur ruang 1, ruang 2, dan ruang 3 diatas, dapat disimpulkan bahwa furnitur utama pada dasarnya berfungsi untuk mendukung aktivitas manusia (Ching, 1996). Selain itu, furnitur juga berfungsi untuk mengoptimalkan fungsi ruang (Wicaksono \& Tisnawati, 2014), khususnya pada tema yang diangkat pada masing-masing ruangannya, namun hal ini tidak berlaku pada ruang 2 karena furnitur utamanya bersifat tunggal. Furnitur pada ketiga ruangan ini memiliki gaya vintage karena berusia puluhan hingga ratusan tahun dan memiliki cerita sehingga membuat barang koleksi tersebut berkesan (Chalmers, 2011). Barang koleksi juga menimbulkan kesan masa lalu yang membuat pengunjung dapat merasakan kembali ke masa lampau (Hasan, 2014). Selain itu, furnitur utama pada ketiga ruangan ini termasuk ke dalam benda heritage karena terdapat sejarah, tradisi, nilai-nilai yang dimiliki oleh suatu bangsa, dan warisan budaya yang perlu dilestarikan oleh generasi selanjutnya karena memiliki nilai luhur (Ardika, 2007).

\subsection{Furnitur Pendukung/ Aksesoris Ruang}

\subsubsection{Furnitur Pendukung/ Aksesoris Ruang 1}

Aksesoris ruang pada ruang $1 \mathrm{~A}$ berfungsi untuk mendukung tema ruangan awal mula perintisan karir Liem Seeng Tee yang terdapat pada furnitur utama dengan nuansa outdoor seperti dekorasi pajangan foto petani tembakau dan penataan tembakau kering dalam keranjang (a), pajangan dinding berupa foto, lukisan, dan tembakau dalam karung (b), serta dekorasi yang hanya digunakan sebagai objek estetik seperti kolom bundar dan tanaman hias 
(c). Aksesoris pada ruang $1 \mathrm{~A}$ ini juga mendukung terbentuknya suatu konsep rustic dilihat melalui pemilihan material berbahan alami seperti keranjang kayu (a), memanfaatkan dekorasi pohon buatan (a), serta terdapat peletakkan karung goni (b).

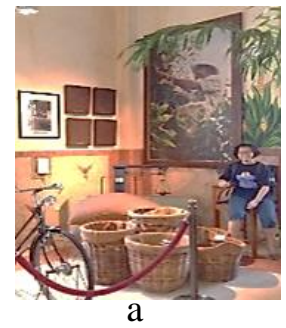

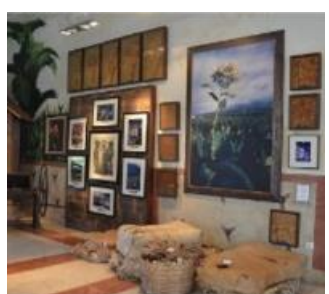

b

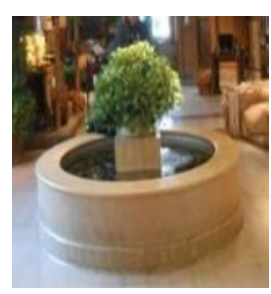

c

Gambar 14. Furnitur Pendukung Ruang 1A

(Sumber a: Andy Setiabudi/Google.com) (Sumber b: casa_mimba/nstagram.com, 2019) (Sumber c: steemit.com, 2019)

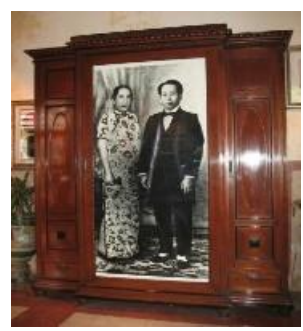

a

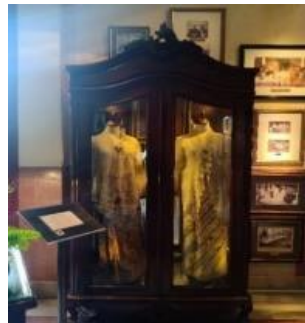

b

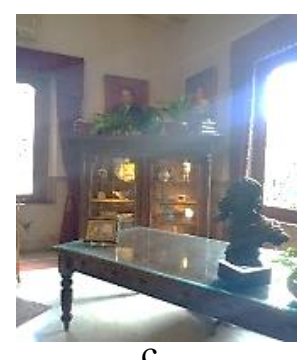

$\mathrm{C}$

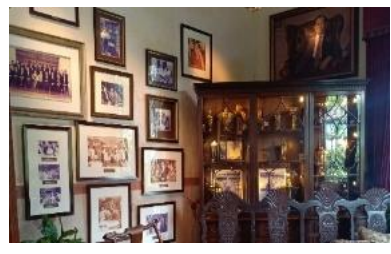

d

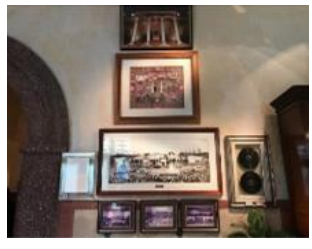

e

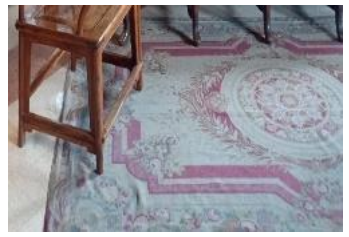

f

\section{Gambar 15. Furnitur Pendukung Ruang 1B}

(Sumber a: tutinonka/wordpress.com, 2008) (Sumber b: Rosyidah Pajak/Google Review) (Sumber c: walterpinem.me) (Sumber e: Citrapolii/Instagram.com, 2018)

Aksesoris ruang pada ruang $1 \mathrm{~B}$ ini juga mendukung tema ruangan tentang keluarga Sampoerna yang bisa dilihat melalui foto Liem Seeng Tee bersama istrinya (a), kebaya encim (b), koleksi keluarga berupa keramik, Guci, dan patung (c), pajangan foto keluarga pendiri Sampoerna dan koleksi trophy milik Aga Sampoerna (d), serta karpet bergaya art nouveau yang memiliki visualisasi ornamen dekoratif tanaman berwarna merah (f). Selain itu, pada ruangan ini juga menampilkan dokumentasi Teater Sampoerna (e) yang menunjukkan bahwa ruangan museum ini dahulu pernah berfungsi sebagai gedung teater.

Aksesoris ruang 1B ini juga menunjukkan adanya gaya vintage perpaduan negara Indonesia dan China yang dapat dilihat pada busana qipao asal China yang dikenakan Liem Seeng Tee bersama istrinya pada pajangan foto (a), dan juga kebaya encim (b) yang merupakan kebaya lokal yang terbentuk dari peleburan budaya peranakan Tionghoa yang tinggal di Indonesia karena pengaruh dari Tiongkok dan Eropa. Adanya perbedaan karakteristik gaya 
vintage yang dipengaruhi oleh kebudayaan ini diidentifikasi termasuk ke dalam konsep eklektik. Eklektik merupakan konsep yang mengkombinasikan dua atau lebih gaya penataan interior (Wicaksono \& Tisnawati, 2014).

\subsubsection{Furnitur Pendukung/ Aksesoris Ruang 2}

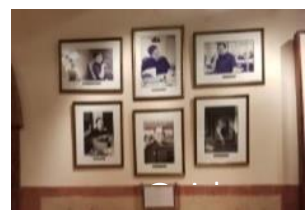

a

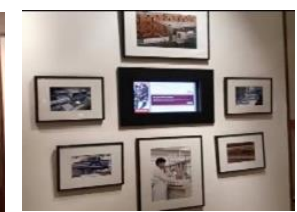

b

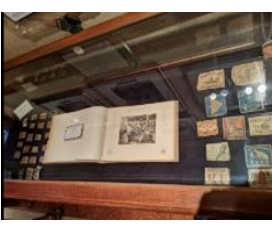

c

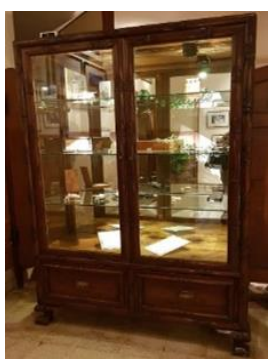

$\mathrm{f}$

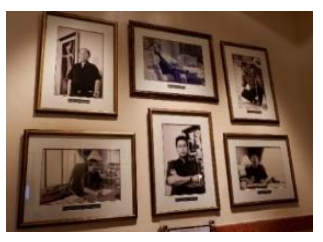

d

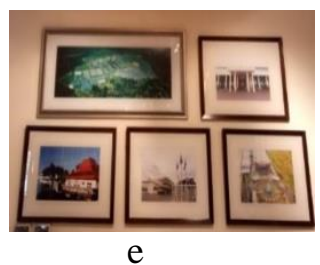

Gambar 16. Furnitur Pendukung Ruang 2A

(Sumber a: Aishaputrina/Instagram.com, 2019) (Sumber b: Liyamusliha/Instagram.com, 2019) (Sumber c: Divakar Jain/Google Review) (Sumber d: Fahmimnoer/Instagram.com, 2017) (Sumber e: Indartanda Pd/ Google Review) (Sumber f: Ela Garini/ Google Review)

Aksesoris ruang pada ruang $2 \mathrm{~A}$ bertujuan untuk menunjang dokumentasi sejarah berupa pajangan foto dalam pigura seperti foto direksi tahun 2002-2005 (a), foto mesin pengecekan kualitas rokok (b), foto komisaris (d), dan foto pabrik rokok Sampoerna di Indonesia (e). Adapula yang bertujuan untuk mengisi kekosongan ruang tanpa adanya unsur sejarah perkembangan bisnis Sampoerna seperti label bungkus korek api (c), dan juga koleksi milik keluarga berupa ashtray, cigarette box, dan lighter (f) yang diletakkan dalam vitrin kayu.

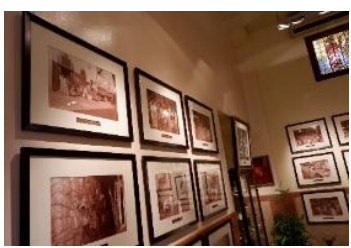

a

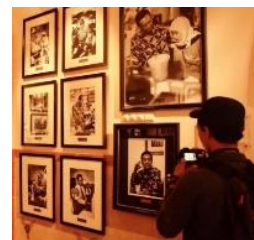

$\mathrm{b}$

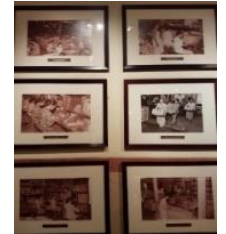

c

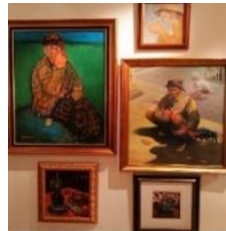

$\mathrm{d}$

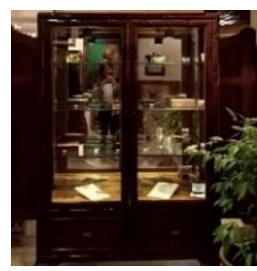

e

Gambar 17. Furnitur Pendukung Ruang 2B

(Sumber a: Fahmimnoer/Instagram.com, 2017) (Sumber b: Goodmorning.toyou/ Instagram.com, 2016)

(Sumber c: Aishaputrina/Instagram.com, 2019) (Sumber d: Cicupied/Instagram.com, 2017) 
Aksesoris ruang pada ruang $2 \mathrm{~B}$ juga sama halnya $2 \mathrm{~A}$ yakni untuk menunjang dokumentasi sejarah berupa pajangan foto dalam figura seperti foto produksi masa lampau (a, c), dan foto mitra produksi sigaret (b). Adapula yang bertujuan untuk mengisi kekosongan ruang tanpa adanya unsur sejarah perkembangan bisnis Sampoerna seperti koleksi lukisan milik keluarga (d) dan koleksi milik keluarga berupa ashtray, cigarette box, dan lighter (f) yang diletakkan dalam vitrin kayu.

Berdasarkan penjelasan diatas, furnitur pendukung pada ruang $2 \mathrm{~A}$ dan $2 \mathrm{~B}$ bersifat tematik, yang berarti memiliki tema yang berbeda tergantung pengelompokkan sejarah pada tata letaknya. Adapula aksesoris ruang yang sengaja ditambahkan untuk mengisi kekosongan ruang berupa koleksi milik keluarga dan sumbangan dari pihak lain (label bungkus korek api). Namun demikian, aksesoris ruang tersebut masih memiliki kesinambungan dengan tujuan perusahaan sebagai produsen rokok. Aksesoris ruang 2 ini tidak mendukung furnitur utama seperti yang dikatakan Ching (1996). Hal ini dikarenakan furnitur utama pada ruang 2 hanya bersifat tunggal atau tidak memerlukan furnitur pendukung lainnya.

Aksesoris ruang pada ruang 2 memiliki gaya vintage yang terkandung unsur heritage sebab benda tersebut memiliki nilai sejarahnya masing-masing. Adapun tata letak aksesoris ruang yang diterapkan yaitu konsep modern minimalis dilihat dari perwujudan komponen dan elemen interior yang sederhana (Suerni, 2013), memanfaatkan elemen garis seperti pada figura dan vitrin sehingga furnitur pendukung terlihat lebih ringkas, penataan terkesan kaku dan dingin (ASRI dalam Badriyah, 2016), dan tidak menggunakan banyak warna yang menonjol (Wicaksono \& Tisnawati, 2014). Adanya kombinasi antara gaya vintage dengan konsep modern minimalis ini termasuk ke dalam konsep eklektik yang berarti memadukan dua atau lebih gaya penataan interior (Wicaksono \& Tisnawati, 2014).

\subsubsection{Furnitur Pendukung/ Aksesoris Ruang 3}

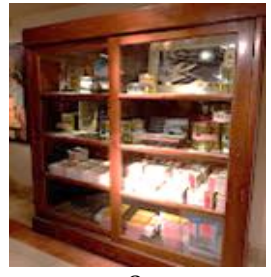

a

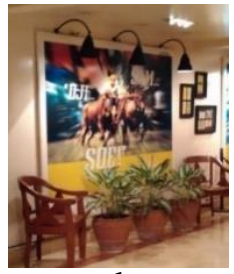

b

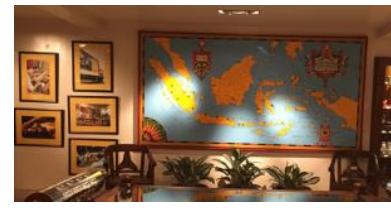

e

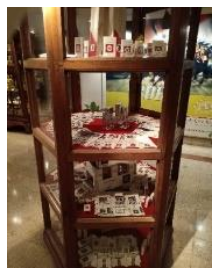

c

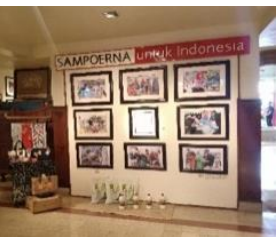

f

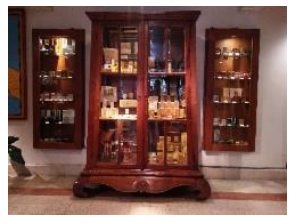

d

Gambar 18. Furnitur Pendukung Ruang 3

(Sumber b: Wibiyanatravels/Blogspot.com, 2016) (Sumber d: Rosita/Travellingyuk.com, 2019) (Sumber e: Adrian/Blog.airpaz.com, 2019)

Furnitur pendukung pada ruang 3 bertujuan untuk mendukung tema furnitur utama seperti bahan cetak (a), dan hasil produksi bungkus rokok (c, d). Namun ada juga yang bertujuan untuk mengisi kekosongan ruang seperti banner iklan Dji Sam Soe (b), serta adapula yang berfungsi untuk menampilkan kelengkapan informasi tentang perusahaan Sampoerna 
seperti peta persebaran kantor area penjualan dan distribusi rokok Sampoerna di Indonesia (e), dan dokumentasi kegiatan Sampoerna Untuk Indonesia, (f) furnitur pendukung berfungsi untuk melengkapi furnitur utama dalam menampilkan tema dan menunjukkan fungsi ruang (Ching, 1996).

Berdasarkan penjelasan furnitur pendukung/ aksesoris ruang 1, 2, dan 3 telah menunjukkan adanya fungsi tersebut. Adanya furnitur pendukung juga menunjang kepekaan terhadap tema yang dihadirkan dan menambah wawasan dari furnitur utama (Suptandar, 1999). Namun demikian, adapula yang bertujuan sebagai objek estetik seperti dekorasi kolam dan tanaman hias. Furnitur pendukung baik pada ruang 1, ruang 2, dan ruang 3 ada yang memiliki kedudukan tidak mendukung sejarah masa lalu tentang perjalanan bisnis Sampoerna, meski demikian furnitur pendukung tetap memiliki kesinambungan dengan tujuan perusahaan Sampoerna sebagai produsen rokok.

\subsection{Layout Ruangan}

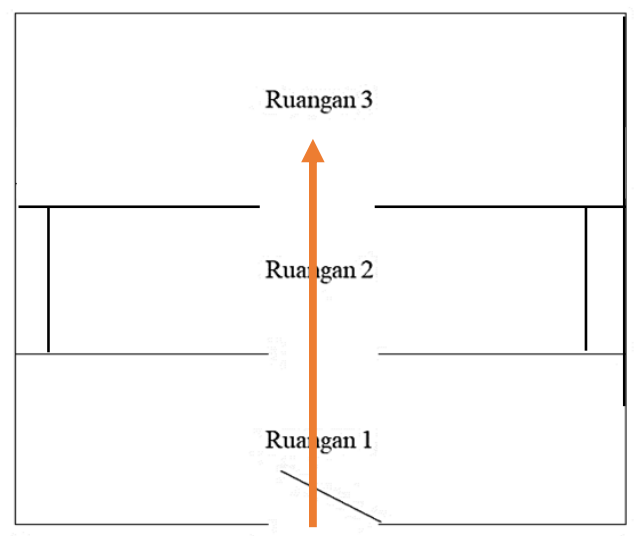

Pintu masuk

Gambar 19. Layout Ruangan

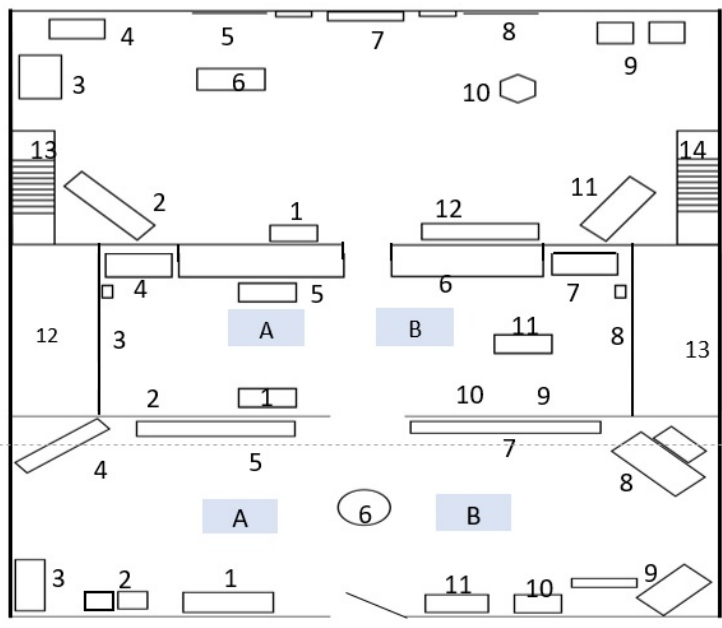

Pintu masuk

Gambar 20. Layout Barang Koleksi

Keterangan:

A = Ruang sebelah kiri $B=$ Ruang sebelah kanan

KETERANGAN RUANG 1: 


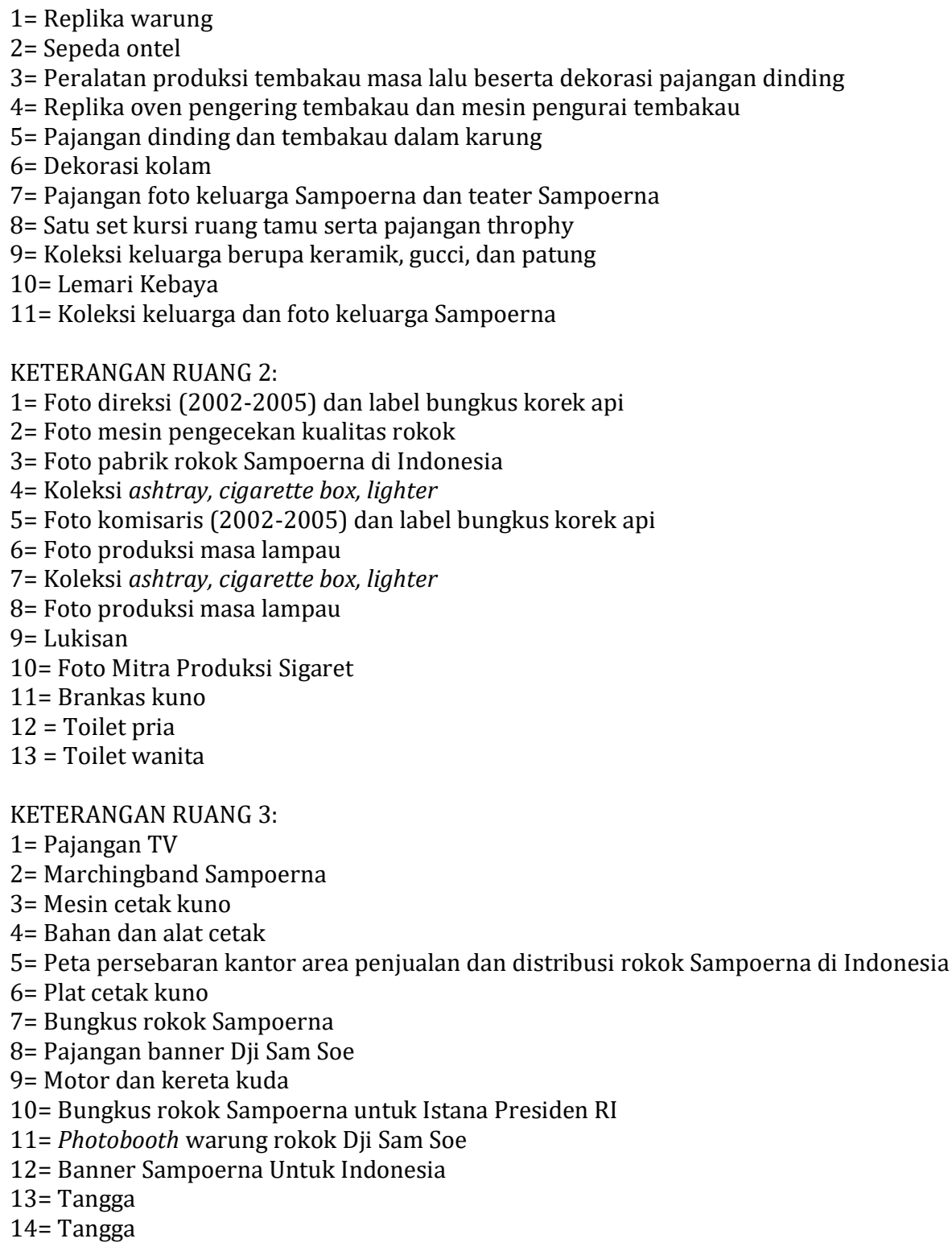

Layout pada ruang 1, ruang 2, dan ruang 3 memiliki organisasi linier melihat dari bentuk ruangannya yang memanjang ke samping serta peletakan storyline yang tidak terulang pada ruangan lainnya. Penataan barang koleksi pada ruang 1, ruang 2 dan ruang 3 ditata mengikuti posisi dinding ruangan sehingga pengunjung dapat mudah menjangkau atau melihat barang koleksi tersebut. Pernyataan tersebut sesuai dengan pendapat Ching (2008) bahwa organisasi ruang linier bersifat memanjang dan memiliki bentuk serta ukuran yang sama besarnya untuk menunjukan adanya arah pergerakan pada ruangan tersebut. Pengunjung bebas memilih untuk berjalan ke sisi kanan atau kiri ruangan terlebih dulu ketika memasuki ruangan.

Namun demikian, hal tersebut justru membuat storyline yang ingin disampaikan menjadi tidak dapat dipahami, atau dalam kata lain pengunjung hanya menikmati keindahan barang koleksinya saja. Hal tersebut didukung oleh penelitian sebelumnya (Limantara dkk, 2017) yang menyatakan bahwa organisasi ruang Museum House of Sampoerna berbentuk linear dengan tujuan supaya pengunjung dapat berkeliling museum sesuai alur yang telah ditentukan, namun menurut hasil pengamatan tidak semua pengunjung mengikuti alur 
museum dikarenakan tidak ada elemen orientasi fisik (wayfinding), seperti peta maupun arah panah yang dapat membantu kunjungan pengunjung.

\section{Simpulan}

Berdasarkan pembahasan di atas dapat disimpulkan bahwa ketiga ruangan pada Museum House of Sampoerna bersifat tematik yang terdiri dari beberapa konsep. Pada ruang 1 menerapkan konsep eklektik-heritage yang memadukan konsep rustic dan gaya vintage tiga negara (Indonesia, China, Belanda). Pada ruang 2 menerapkan konsep eklektik-heritage yang memadukan gaya vintage dan minimalis modern. Pada ruang 3 menerapkan konsep vintageheritage.

\section{Ucapan Terimakasih}

Peneliti mengucapkan terima kasih kepada ibu Dra. Lilik Indrawati, M.Pd dan ibu Swastika Dhesti Anggriani atas bimbingannya, serta seluruh pihak yang bersangkutan selama pelaksanaan penelitian ini, sehingga penelitian dapat berjalan dengan baik dan lancar.

\section{Daftar Rujukan}

Ardika, I.W. (2007). Pustaka budaya dan pariwisata. Denpasar: Pustaka Larasan.

Badriyah, S. (2016). Fenomena budaya desain minimalis masyarakat kota. ISI Surakarta.

Ching, F.D.K. (1996). Ilustrasi desain interior. Jakarta: Erlangga.

Ching, F.D.K. (2008). Arsitektur bentuk, ruang, dan tatanan: Edisi ketiga. Jakarta: Erlangga.

Chalmers, E. (2011). Modern vintage style. New York: Ryland Peters \& Small.

Ching, F.D.K., \& Binggeli, C. (2012). Interior design illustrated. New Jersey: John Wiley \& Sons, Inc.

Hasan, L. (2014). Vintage on weekend. Jakarta: Jakartavintage.co.

Jelajah Nesia 2. (2015). Brankas kuno yang unik di House of Sampoerna. http://jelajahnesia2.blogspot.com/2015/03/brankas-kuno-yang-unik-di-house-of.html?m=1. Diakses pada 30 April 2021 pukul 21.05 WIB.

Limantara, O., Kristianto, T.A., \& Kattu, G.S. (2017). Pengaruh interior terhadap perilaku pengunjung museum House of Sampoerna Surabaya. Jurnal Intra, 5(2): 811-819.

Mangunwijaya, Y.B. (1980). Pasal-pasal pengantar fisika bangunan. Jakarta: Gramedia.

Suptandar, J.P. (1985). Perancangan tata letak ruang dalam. Jakarta: Fakultas Teknik Sipil dan Perencanaan Universitas Tri Sakti.

Suptandar, J.P. (1999). Desain interior pengantar merancang interior untuk mahasiswa desain dan arsitektur. Jakarta: Djambatan.

Suerni, T. (2013). Desain interior rumah tinggal minimalis. Jakarta: Direktorat Pembinaan SMK 2013.

Santoso, I.N., \& Santosa, A. (2013). Gaya desain kolonial Belanda dan Cina pada interior Hotel Ganefo Surabaya. Jurnal Intra, 1(1): 1-13.

Sugiyono. (2019). Metode penelitian kuantitatif, kualitatif dan R\&D. Bandung: Alfabeta.

Munandar, A.A., Perdana, A., Rahayu, A., Gultom, A.M., Susanto, D., Asiarto, L., Supardi, N., Tjahjopurnomo, R. (2011). Sejarah permuseuman di Indonesia. Direktorat Permuseuman, Direktorat Jenderal Sejarah dan Purbakala, Jakarta: Kementerian Pariwisata dan Badan Ekonomi Kreatif.

Tanoko, F.K. (2013). Penerapan gaya eklektik pada interior Dream of Kahyangan Art Resto Surabaya. Dimensi Interior, 11(1): 11-21.

Wilkening, F. (1989). Tata ruang. Yogyakarta: Kanisius.

Wicaksono, A.A., \& Tisnawati, E. (2014). Teori interior. Jakarta: Griya Kreasi (Penebar Swadaya Grup).

Young, K.M. (2000). Architecture \& design library: Art deco. New York: Michael Friedman Publishing Group, Inc. 